\title{
Compliance with IAS 2 in Consolidated Financial Statements of PSE Listed Companies
}

\author{
Kateřina Polachová*
}

\begin{abstract}
:
As inventories represent a significant balance sheet item for many companies, their correct presentation and disclosure is fundamental for the financial statements' users. This article identifies compliance with the "IAS 2 Inventories" requirements in consolidated financial statements of selected Czech companies. After determining criteria for the issuer's sample, two research questions were set up for the evaluation of compliance measures with IAS 2. The research focuses on the association between the sum of total assets and the sum of inventories as well as an association between the sum of inventories and their allowances. Investigation is followed by the determination of compliance or non-compliance with the requirements of IAS 2 .

The research leads to the conclusion that the sum of inventories depends on the sum of assets. However, the sum of inventories' allowances does not depend on the sum of inventories. As far as the area of compliance with the IAS 2 requirements is concerned, on average, issuers did not comply with 3 out of total 8 IAS 2 requirements. The most problematic area of compliance was how reversals of writedowns were disclosed. The second most problematic requirement was a write-down justification and the third most problematic requirement was a disclosure of pledged inventories.
\end{abstract}

Key words: IAS 2; inventories; allowances; IFRS disclosure.

JEL codes: M41.

\section{Introduction}

In the Czech Republic there exist various business types for which inventories represent the essential part of assets. Most commonly, inventories are understood as short term assets held for sale comprising material, work in progress, finished products and/or goods. Their structure and volume depends on the given company`s sector of business.

In annual reports published in Czech Republic, inventories are regulated by either the Czech GAAP or IFRS. In the Czech legislation, there is clearly stated what kind

* Kateřina Polachová; University of Economics, Prague, Faculty of Finance and Accounting Department of Financial Accounting and Auditing, W. Churchill Sq. 4, 13067 Prague, Czech Republic, <xpolk13@vse.cz>.

The article is processed as an output of a research project Market failures and their impact on audit quality in the Czech Republic registered by the Grant Agency of University of Economics, Prague under the registration number F1/25/2019. 

Companies.

of guidelines the companies should use for the preparation of their annual reports. In this article are examined companies which prepare their annual reports in line with the IFRS requirements. The reason for performing research on annual reports prepared in line with IFRS is due to the fact that inventories disclosure guidance in the Czech GAAP is less detailed than in IFRS, or more precisely, in IAS 2.

Compilation of an annual report in line with the IFRS requirements is more challenging on the consolidation level than on the individual level. This is mainly due to collection of information from subsidiaries and associates, which tends to be complicated and time consuming. As a result of such complications, it is possible that a consolidated annual report would not precisely comply with the IFRS requirements. Therefore, our research was focused on consolidated annual reports.

The results from literature review show that compliance with IAS 2 in consolidated annual reports of the Czech companies has not yet been performed, despite the fact that possible results could bring fruitful information and disclosure relating to compliance with IAS 2 .

The aim of the presented article is to assess the extent of compliance with the IAS 2 disclosure requirements. Inventories could be a very significant item in the company's balance sheet, as further mentioned by Monea (2011, p. 183): "In many businesses, inventories are the most important assets. Accounting for inventories is a major consideration for many entities because of its significance for both the income statement (cost of goods sold) and the statement of financial position. The complexity of accounting for inventories arises from several factors, such as the high volume of activity, the various cost flow alternatives that are acceptable, and the classification of inventories."

This article contains review of inventory and compliance literature, assessment of research questions and determination of a relevant sample that is followed by research results and conclusions.

The research has proved that within the examined sample of consolidated annual reports there exists an association between the sum of inventories and the sum of assets. The investigation also indicated that on average companies did not comply with three of eight IAS 2 requirements in their consolidated financial statements. The research has revealed that the level of disclosure compliance with IAS 2 is comparable to the compliance with other standards investigated by authors from the literature review. 


\section{Literature Review}

\subsection{Disclosure Quality/Compliance Literature Review}

Compliance with the IFRS requirements has been examined in many articles. The following five paragraphs summarise the most relevant articles which examine the disclosure quality of financial statement of companies listed on the Prague Stock Exchange (hereinafter "PSE") and prepared in accordance with the IFRS requirements. This demonstrates that disclosure quality of companies listed on PSE is a very important area of research in the Czech Republic. The last two papers examine the disclosure and compliance with IFRS in European countries on their stock markets and testify that the stock market is a very important area to be examined.

The quality of disclosure under IAS 38 intangible assets in financial statements of entities listed on PSE was examined by Novák (2018). The paper has revealed a poor level of disclosure quality within the sample of the listed companies in 2015. Examination of the fulfilment of IFRS 2 share-based payment disclosure requirements by companies listed on PSE, performed by Červený (2017), proved that issuers met requirements of IFRS 2, but they were not able to use advanced valuation methods and the presentation was shorter when compared to their German counterparts.

The research performed by Čavela (2016) proved satisfactory quality of information disclosed in annual reports of listed companies in the Czech Republic required by regulations. Čavela determined 40 basic requirements which should be contained in each part of the AR and examined its compliance.

Research performed by Dvořák (2017) concluded that in regard to the IFRS 13 requirements of fair value presentation, companies in the Czech Republic failed to report compulsory information.

Compliance with the IAS 7 statement of cash flows by issuers of listed securities in the Czech Republic was tested by Brabcová (2018). Her research concluded that issuers comply with IAS 7 requirements in general; however, no issuer disclosed voluntary information.

Determination of whether the application of the same set of accounting standards may result in differences in the information provided due to discrepancies in institutional factors in the countries where the reporting firms are located was performed by Barbu, Dumontier, Feleaga and Feleaga (2014). Research of compliance with mandatory environmental disclosures was focused on companies from Germany, France and the United Kingdom in sectors such as technology, healthcare, industrials, basic materials and cyclical consumer goods and services. The analysis of annual reports realised in IAS/IFRS interprets that out 
Polachová, K.: Compliance with IAS 2 in Consolidated Financial Statements of PSE Listed Companies.

of the sample of 114 companies from the examined countries and sectors, only two provided environmental information in compliance with requirements of IFRS in the inventories area (waste, specifically).

Research relating to the IAS 2, IAS 11 and IAS 37 disclosure of companies listed on the stock markets of London, Germany and Paris was performed by Mateiu (2013). The disclosure was examined for all the three standards together and the research demonstrated that there was a positive relationship between information disclosed in the financial statements, and the selected financial ratios. Analysed variables were earnings per share, book value of the share, rate of return on equity, natural logarithm of turnover, auditor`s type and disclosure index.

\subsection{Review of research related to inventory issues}

Importance of inventories' examination is demonstrated by the following articles. Research of inventories is performed not only in Czech Republic but also in other countries around the world.

A description of basic requirements of IAS 2 and a comparison with the Czech accounting legislation requirements was performed in the article of Král. (2014). Seven changes to the definition and valuation of inventories were suggested in the article. These changes should be, according to Král, incorporated into the Czech accounting legislation, into the Czech standards, or their interpretations.

The difficulties with the International Financial Reporting Standards application (including IAS 2) among the agricultural organisations of the Russian Federation were examined by Sytnik (2013).

The IAS 2 Inventories also require impairment of inventories to be recognised, while the Greek GAAP merely required a disclosure (Tsalavoutas, Andre \& Evans, 2012).

Comparison between the requirements of US GAAP and IFRS (respectively IAS 2) and use of the cost of goods sold under FIFO and LIFO in financial statements of US companies was performed and published by Jeffers and Askew in 2010.

The impact of changing the accounting method for inventory from LIFO to FIFO in the US accounting standards, which was proposed by SEC within the full adoption of IFRS, was examined by Comiskey, Mulford and Thomason (2008). They examined the income, balance sheet, cash flow and tax effects of a change of the method from LIFO to FIFO.

The research of inventory valuation under IFRS and US GAAP was also performed by Krishnan and Ling (2012); they examined differences of all standards relating to inventories. The research was focused on companies within the manufacturing sector with focus on oil and gas industries, pharmaceutical industry, and on companies involved in merchandising; specifically in consumer goods retailing. 
Examination of compliance with the IAS 2 requirements was selected due to the fact that inventories are frequently considered significant items in financial statements and existing research in the area of inventory valuation and presentation is insufficient and incomplete. On the other hand, disclosure quality research is frequently examined and results of research of compliance with IAS 2 by issuers listed on PSE could extend and contribute to researches already performed.

Objectives of paper were divided into the following research questions:

- Q1: Do issuers meet requirements of IAS 2 in their financial statements, and if so, to what extent?

- Q2: What are the determinants of the compliance level?

\section{Data and Methodology}

Research has been performed on annual reports of the issuers of listed shares at PSE, itself a part of the European regulated market. The list of issuers of the listed shares is supervised and managed by Czech National Bank. The requirement for listed entities to publish an audited Annual Report prepared in compliance with IFRS (including Financial Statements) is stated in the Act on Accounting No. 563/1991 Coll. Methods and deadlines for publishing are stated by the Public Notice No. 234/2009 Coll. and by the Act No. 256/2004 Coll., On Capital Market Business and are subsequently managed by Czech National bank. These reports must be prepared in accordance to the IFRS.

Data and information publicly available at the register of CNB, companies' web sites, the public register and web site of PSE have been used.

These statements were used as a vital base for the research of the consolidated level of company. The research was started on 17 February 2019. In total, $119^{1}$ issuers of the listed securities were registered at the CNB register to that date. However, not all the subjects were relevant for this research. To get a relevant sample, subjects like banks, insurance companies, investment companies and investment funds were excluded, as these subjects have no or very little inventories in general. After this first reduction, the list of potentially relevant companies amounted to 54 . Furthermore, the capital city of Prague was left out from the list, leaving 53 companies in the relevant sample. Twenty companies from the sample had no available consolidated financial statements and were therefore excluded as well. These companies either did not prepare consolidated financial statements or their statements were not published. The final, relevant examined sample therefore

\footnotetext{
${ }^{1}$ For the complete list of issuers of listed securities, please refer to the CNB register.
} 
Polachová, K.: Compliance with IAS 2 in Consolidated Financial Statements of PSE Listed Companies.

contained 33 issuers of listed securities with comparable information in financial statements published via platforms mentioned above.

\section{Fig. 1: Selection process of issuers}

- Total number of issuers of listed securities in the CNB register
$\begin{aligned} & \text { Number after excluding } 65 \text { irrelevant subjects - banks, insurance companies, investment } \\ & \text { funds and companies }\end{aligned}$
$\begin{aligned} & \text { - Final examined number after excluding } 20 \text { companies which had no available annual } \\ & \text { reports on available platforms }\end{aligned}$
$\begin{aligned} & \text { Final sample after excluding } 5 \text { companies which had no inventories in consolidated } \\ & \text { financial statements }\end{aligned}$

Source: Own research

Areas and requirements of the research were determined in accordance with requirements of IAS 2 Inventories. The author decided to use a checklist with applicable requirements which each company should have presented in its financial statements. The checklist is as follows:

\section{Checklist - IAS 2 requirements}

\section{IAS 2.36 Disclose:}

- IAS 2.36(a): the accounting policies adopted in measuring inventories, including the cost formula used;

- IAS 2.36(b): the total carrying sum of inventories and the carrying sum in classifications appropriate to the entity;

- IAS 2.36(c): the carrying sum of inventories carried at fair value less costs to sell;

- IAS 2.36(d): the sum of inventories recognised as an expense during the period;

- IAS 2.36(e): the sum of any write-down of inventories recognised as an expense in the period in accordance with IAS 2.34;

- IAS 2.36(f): the sum of any reversal of any write-down that is recognised as a reduction in the sum of inventories recognised as expense in the period in accordance with IAS 2.34;

- IAS 2.36(g): the circumstances or events that led to the reversal of a write-down of inventories in accordance with IAS 2.34;

- IAS 2.36(h) the carrying sum of inventories pledged as security for liabilities. 
Requirements to comparable information about the sum of inventories, their allowances and the sum of total assets have been added to the examined area. Tested were consolidated financial statements for 2017 and the comparable period was therefore 2016. As of the date of the research, financial statements for 2018 were not available for most of the issuers included in the sample.

Statistical methods used for investigation purposes were summary descriptive statistics, correlation analysis, and analysis of variance. Fundamental for this paper was the analysis of financial statements. Another technique used was a correlation analysis. All results with relevant diagrams are presented in Section 4 Results and Discussion.

\section{Results and Discussion}

Examination was performed on consolidated financial statements of issuers of the listed securities which are managed in the CNB register. For the purposes of testing, a relevant sample of 33 financial statements was used following the removal of all the inappropriate entities as mentioned above. When analysing the financial statements included in the sample, it was found that 5 consolidated financial statements did not contain inventories and these were therefore also not relevant for testing.

Research was performed on consolidated financial statements since IFRS standards are primary oriented on big consolidated groups. For issuers, preparation of a consolidated annual report is also more difficult; e.g. collection of all the relevant information on subsidiaries or fulfilment of all the requirements could be laborious.

The final number of relevant financial statements amounted to 28. Collected information from consolidated balance sheets on the amount of inventories, assets and allowances to inventories summarise the descriptive statistics below.

Note that companies in the sample ranked under various business sectors and therefore had also different structures of inventories. Sectors of the researched companies and their inventory structures were as follows: railway (spare parts), real estate (projects and property for resale), telecommunication (goods and merchandise, work in progress, finished products, material), industrial transportation (spare parts, material, work in progress), tobacco (goods and material), manufacturing (material, work in progress, finished products, goods), hotel (material, goods, property for sale), beverages (material, finished products, goods), healthcare, entertainment (material and goods), energy (material, work 
Polachová, K.: Compliance with IAS 2 in Consolidated Financial Statements of PSE Listed Companies.

in progress, finished products, natural gas), gas (material, goods, natural gas), electricity (fossil fuel), heat (material), rental (material), advertising (not stated) and textile (material, finished products and spare parts). Individual sectors of the reviewed companies are stated in Tab.3.

Tab. 1: Summary of descriptive statistics for 2017 (CZK thousand)

\begin{tabular}{lrrrrr}
\hline & $\begin{array}{c}\text { Inventories } \\
\text { Va17 }\end{array}$ & $\begin{array}{c}\text { Sum of assets } \\
\mathbf{2 0 1 7}\end{array}$ & $\begin{array}{c}\text { Inventories/ } \\
\text { Sum of assets }\end{array}$ & $\begin{array}{c}\text { Allowance of } \\
\text { inventories } \\
\mathbf{2 0 1 7}\end{array}$ & $\begin{array}{c}\text { Allowance/ } \\
\text { Inventories } \\
\mathbf{2 0 1 7}\end{array}$ \\
\hline average & $3,106,653$ & $175,696,131$ & $5.35 \%$ & 40,511 & $3.72 \%$ \\
median & 175,151 & $11,488,528$ & $2 \%$ & 15,232 & $0 \%$ \\
min & 1,118 & 348,648 & $0 \%$ & 485 & $0 \%$ \\
max & $51,064,125$ & $3,635,817,150$ & $38 \%$ & 339,000 & $31 \%$ \\
bottom quartile & 32,546 & $3,190,757$ & $1 \%$ & 2,904 & $0 \%$ \\
upper quartile & $1,670,014$ & $37,440,000$ & $5 \%$ & 133,184 & $4 \%$ \\
Pearson`s & & & & & 0.1087 \\
Correl. Coeff. & & & Deeply below 0.05 & & 0.582 \\
P-value & & &
\end{tabular}

Source: Own research based on publicly available consolidated financial statements

Tab. 2: Summary of descriptive statistics for 2016 (CZK thousand)

\begin{tabular}{lrrrrr}
\hline & $\begin{array}{c}\text { Inventories } \\
\mathbf{2 0 1 6}\end{array}$ & $\begin{array}{c}\text { Sum of assets } \\
\mathbf{2 0 1 6}\end{array}$ & $\begin{array}{c}\text { Inventories/ } \\
\text { Sum of assets }\end{array}$ & $\begin{array}{c}\text { Allowance of } \\
\text { inventories } \\
\mathbf{2 0 1 6}\end{array}$ & $\begin{array}{c}\text { Allowance/ } \\
\text { Inventories } \\
\mathbf{2 0 1 6}\end{array}$ \\
\hline average & $2,592,617$ & $179,240,142$ & $5.33 \%$ & 40,204 & $2.81 \%$ \\
median & 156,311 & $9,715,620$ & $2 \%$ & 17,104 & $0 \%$ \\
min & 1,118 & 354,250 & $0 \%$ & 80 & $0 \%$ \\
max & $41,604,660$ & $3,792,306,900$ & $38 \%$ & 299,256 & $31 \%$ \\
bottom quartile & 31,533 & $2,205,676$ & $1 \%$ & 4,220 & $0 \%$ \\
upper quartile & $1,542,423$ & $24,623,354$ & $5 \%$ & 209,841 & $3 \%$ \\
Pearson`s & & & & & 0.0972 \\
Correl. Coeff. & & & Deeply below 0.05 & & 0.6225 \\
P-value & & &
\end{tabular}

Source: Own research based on publicly available consolidated financial statements

There is a strong association between the sum of assets and the sum of inventories.

There is no association between the sum of inventory allowances and the sum of inventories, which means that the sum of inventory allowances does not depend on the sum of inventories. 
The research shows that all issuers comply with the requirement of $\boldsymbol{I A S} \mathbf{2 . 3 6}(\boldsymbol{b})$ and state in the financial statements for both periods the total carrying sum of inventories and the carrying sum in classifications appropriate to the entity.

Total assets and inventories compared to the prior year remained stable with minimal Year-to-year (hereinafter "YtY") change, except for the significant increase in the amount of assets of the issuer 3 ORCO PROPERTY GROUP S.A., and the significant increase in the amount of inventories of the issuer 7 CZECHOSLOVAK GROUP a.s. Allowances-to-inventories changed mostly in the case of the first issuer České dráhy a.s. where there was a decrease in allowancesto-inventories, and in the case of the sixth issuer ŠKODA TRANSPORTATION a.s., where allowances had increased.

Issuers included in the sample have a different line of business and a different sum of total assets, and therefore they also have a different value of inventories. The biggest issuer, DEUTSCHE TELECOM AG, with the total sum of assets CZK $3,635,817$ million, had the inventory amounting to only $1.4 \%$ of the total assets due to its line of business. On the other hand, the issuer with the biggest share of inventories in total assets is Česká zbrojovka a.s., which had total assets CZK 4,777 million $(37.7 \%)$. Due to this fact it was necessary to examine the relation between the sum of inventories in the sum of total assets and the relation between the sum of allowances in the sum of inventories for both periods.

\section{Q1: Do issuers meet requirements of IAS 2 in their financial statements, and if so, to what extent?}

In this research, compliance and non-compliance in consolidated financial statements of issuers of the listed securities with requirements of IAS 2 was examined. For this purpose, the checklist was used with the 8 stated areas of compliance. One of these areas IAS 2.36(b) is described above; the table below therefore shows only results of the remaining 7 areas. 
Polachová, K.: Compliance with IAS 2 in Consolidated Financial Statements of PSE Listed Companies.

Tab. 3: Compliance/non-compliance with the IAS 2 requirements

\begin{tabular}{|c|c|c|c|c|c|c|c|c|}
\hline requirements & $\mathbf{a}$ & c & d & e & f & g & h & \\
\hline $\begin{array}{l}\text { Issuer's } \\
\text { Number }\end{array}$ & $\begin{array}{c}\text { Accounti } \\
\text { ng } \\
\text { policies } \\
\text { IAS 2 }\end{array}$ & $\begin{array}{c}\text { FV } \\
\text { of } \\
\text { inventori } \\
\text { es }\end{array}$ & $\begin{array}{c}\text { Inventor } \\
\text { ies } \\
\text { expenses }\end{array}$ & $\begin{array}{c}\text { Write } \\
\text { down of } \\
\text { inventori } \\
\text { es in } \\
\text { expense }\end{array}$ & $\begin{array}{c}\text { Reversal } \\
\text { s of } \\
\text { write } \\
\text { down }\end{array}$ & $\begin{array}{c}\text { Reason } \\
\text { of write } \\
\text { down }\end{array}$ & $\begin{array}{c}\text { Pledged } \\
\text { inventori } \\
\text { es }\end{array}$ & $\begin{array}{l}\text { Num. of } \\
\text { No }\end{array}$ \\
\hline 1 & yes & yes & yes & Yes & no & no & yes & 2 \\
\hline 2 & yes & yes & yes & No & no & no & no & 4 \\
\hline 3 & yes & yes & yes & No & no & no & no & 4 \\
\hline 4 & yes & yes & yes & No & no & no & no & 4 \\
\hline 5 & yes & yes & yes & Yes & no & no & no & 3 \\
\hline 6 & yes & yes & yes & Yes & no & yes & no & 2 \\
\hline 7 & yes & yes & yes & Yes & no & no & yes & 2 \\
\hline 8 & yes & yes & yes & Yes & yes & yes & yes & 0 \\
\hline 9 & yes & yes & yes & No & no & no & yes & 3 \\
\hline 10 & yes & yes & yes & No & no & no & no & 4 \\
\hline 11 & yes & yes & yes & No & no & no & no & 4 \\
\hline 12 & yes & yes & yes & No & no & no & yes & 3 \\
\hline 13 & yes & yes & yes & No & no & no & no & 4 \\
\hline 14 & yes & yes & yes & Yes & yes & yes & yes & 0 \\
\hline 15 & yes & yes & yes & Yes & yes & yes & no & 1 \\
\hline 16 & yes & yes & yes & Yes & yes & yes & no & 1 \\
\hline 17 & yes & yes & yes & Yes & no & no & no & 3 \\
\hline 18 & yes & yes & yes & No & no & no & no & 4 \\
\hline 19 & yes & yes & yes & Yes & yes & yes & yes & 0 \\
\hline 20 & yes & yes & yes & Yes & yes & yes & no & 1 \\
\hline 21 & no & no & yes & no & no & no & no & 6 \\
\hline 22 & no & no & no & no & no & no & no & 7 \\
\hline 23 & yes & yes & yes & yes & yes & yes & no & 1 \\
\hline 24 & yes & yes & yes & yes & yes & yes & yes & 0 \\
\hline 25 & no & no & no & no & no & no & yes & 6 \\
\hline 26 & yes & yes & yes & no & no & no & no & 4 \\
\hline 27 & yes & yes & yes & yes & no & no & no & 3 \\
\hline 28 & yes & yes & yes & no & no & no & yes & 3 \\
\hline $\begin{array}{l}\text { Number } \\
\text { of non- } \\
\text { compliance }\end{array}$ & 3 & 3 & 2 & 14 & 20 & 19 & 18 & 79 \\
\hline Ratio $^{2}$ & $11 \%$ & $11 \%$ & $7 \%$ & $50 \%$ & $71 \%$ & $68 \%$ & $64 \%$ & $40 \%$ \\
\hline
\end{tabular}

Source: Own research based on publicly available consolidated financial statements

2 This ratio represents share of how many issuers did not comply with a particular requirement. 
For detail please refer to Amendment 1.

Note that in the compliance research, 7 requirements of IAS 2 were tested; the "no's" in the table represent the number of requirements which issuers did not state in their consolidated financial statements.

However, it cannot be stated from the examination whether issuers omitted the presentation of the requirement in its consolidated financial statements or whether a requirement was just not relevant for them.

Compliance with the IAS 2 requirements was also subsequently examined from other perspectives, as presented below.

If and what extent issuers in their consolidated financial statements meet requirements of IAS 2?

As it is clear from Tab. 4, only 4 issuers comply with all the requirements of IAS 2 and only one issuer does not comply with any of the requirements. Most issuers comply at least partially with IAS 2 requirements. The most problematic requirement was presentation of a reversal of a write-down where $71 \%$ of the examined issuers did not comply. Presentation of a reason of a write-down was the second problematic requirement where $68 \%$ of issuers did not comply. Presentation of pledged inventories was not stated in $64 \%$ of the examined issuers' consolidated statements. Half of the issuers also did not comply with the requirement of a writedown of inventories in expenses. Only $11 \%$ of issuers did not comply with the requirement of presentation of FV of inventories and Accounting policies IAS 2. The biggest compliance was in the inventory expenses requirement.

\section{Fig. 2: Number of non-compliance with the IAS 2 requirements in (\%)}

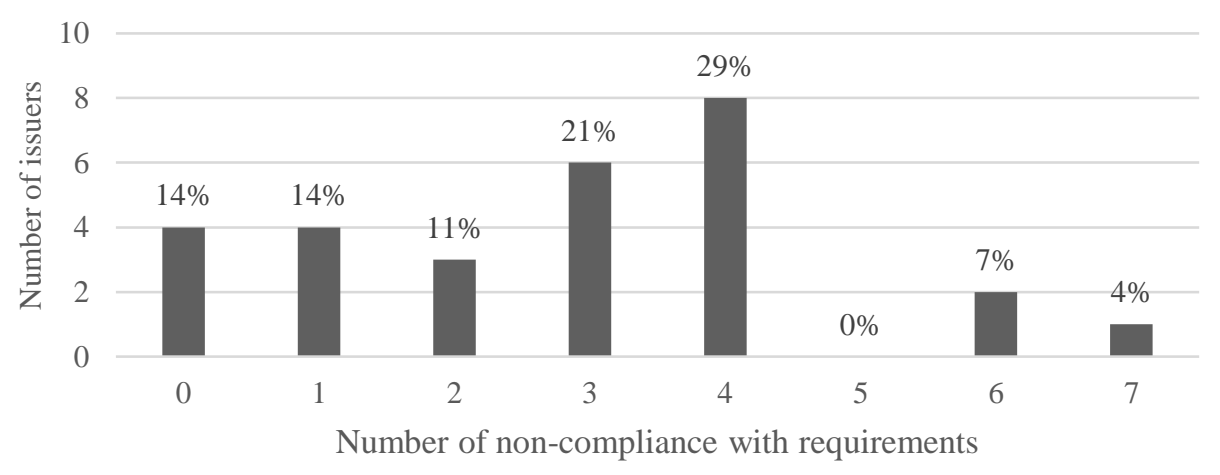

Source: Own research 
Polachová, K.: Compliance with IAS 2 in Consolidated Financial Statements of PSE Listed Companies.

Based on the research results, only $14 \%$ of the issuers fully comply with the IAS 2 requirements. The same share of issuers did not comply with one requirement mainly is area of pledged inventories. Three issuers (11\%) did not comply with two requirements. One of them did not comply with the pledge of inventories and reversal of a write-down, the other did not comply with reversal of a write-down and its reason. Six issuers (21\%) did not comply with three requirements; problematic areas for them were: presentation of a write-down of inventories in expenses, reversal of a write-down and a relevant comment. The biggest part of issuers $29 \%$ ( 8 issuers) did not comply in four requirements. Two issuers (7\%) did not comply in almost all requirements; only one requirement was fulfilled inventories expenses or rather pledged inventories. Zero requirements were fulfilled only in the case of one issuer.

On average, the measure of issuer`s non-compliance amounted to $40 \%$. Compared to the research on disclosure conducted by other authors, issuers comply with the IAS 2 requirements on a conformable level. Research by Dvořák revealed that 65$74 \%$ of companies comply with the requirement of IFRS 13- measurement of fair value. Červený examined several areas of the IFRS 2 requirements and his overall results can be simplified that more than half of the examined companies fulfil requirements. Research of Brabcová proved that a significant number of the Czech listed companies comply with the basic IAS 7 requirements. Also the research by Čavela has concluded that companies inform their stakeholders well and in the material aspects they meet the regulatory requirements. On the other hand, the research of Novák revealed a poor level of disclosure of intangible assets in financial statements of the companies listed on PSE.

\section{Q2: What are the determinants of the compliance level?}

Is there any association between non-compliance and number of years managed in the CNB register?

In the sample, there are subjects with different history of listed issuers of shares managed by the CNB register. The period of coverage vary between 1 and 26 years. According to the results obtained using Pearson's correlation coefficient, there is no relationship between measuring of non-compliance and the number of years being listed. 
Fig. 3: Association between number of years on PSE and compliance with the IAS 2 requirements

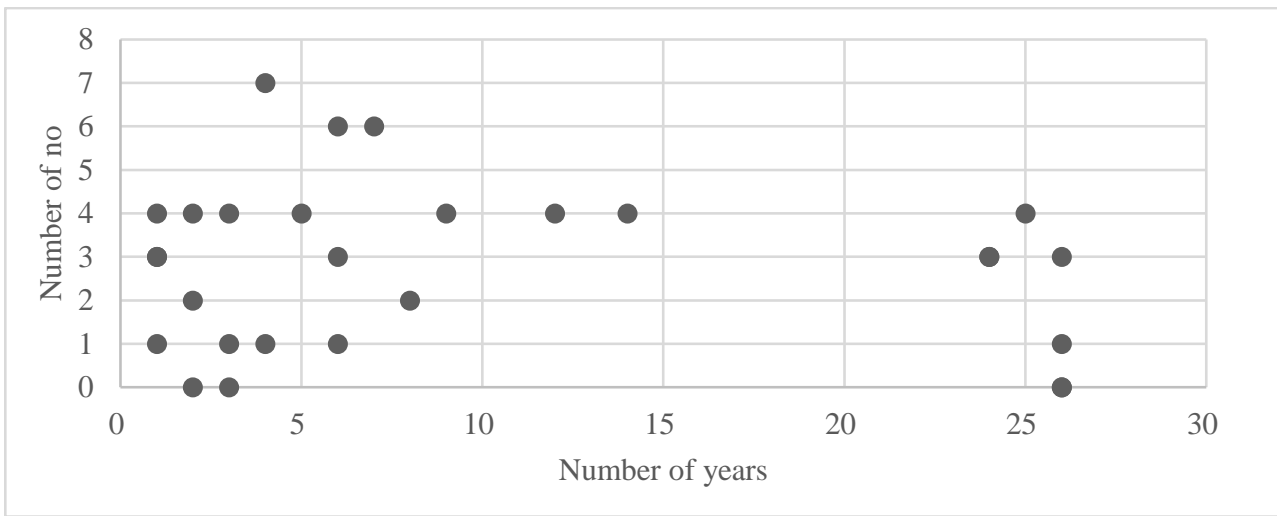

Source: Own research

Is there an association between non-compliance and a sum of assets, or rather a sum of inventories of an issuer?

The research further focused on the association between the measurement of noncompliance with the IAS 2 requirements and the sum of total assets of an issuer, or rather the sum of inventories. Using Pearson's correlation coefficient, no positive association was established in either case, and the examined variables were found to be independent.

\section{Tab. 4: Anova}

\begin{tabular}{lrr}
\hline & F & P-value \\
\hline sum of assets 2017 & 0.2635 & 0.9711 \\
sum of assets 2016 & 0.2567 & 0.9732 \\
sum of inventories 2017 & 0.2323 & 0.9803 \\
sum of inventories 2016 & 0.2294 & 0.9810 \\
\hline
\end{tabular}

Source: Own research

Analysis of variance established that there exists an association between noncompliance and examined variables. 
Polachová, K.: Compliance with IAS 2 in Consolidated Financial Statements of PSE Listed Companies.

Is there an association between non-compliance and an auditing company?

Fig. 4: Association between level of non-compliance and company`s statutory auditor

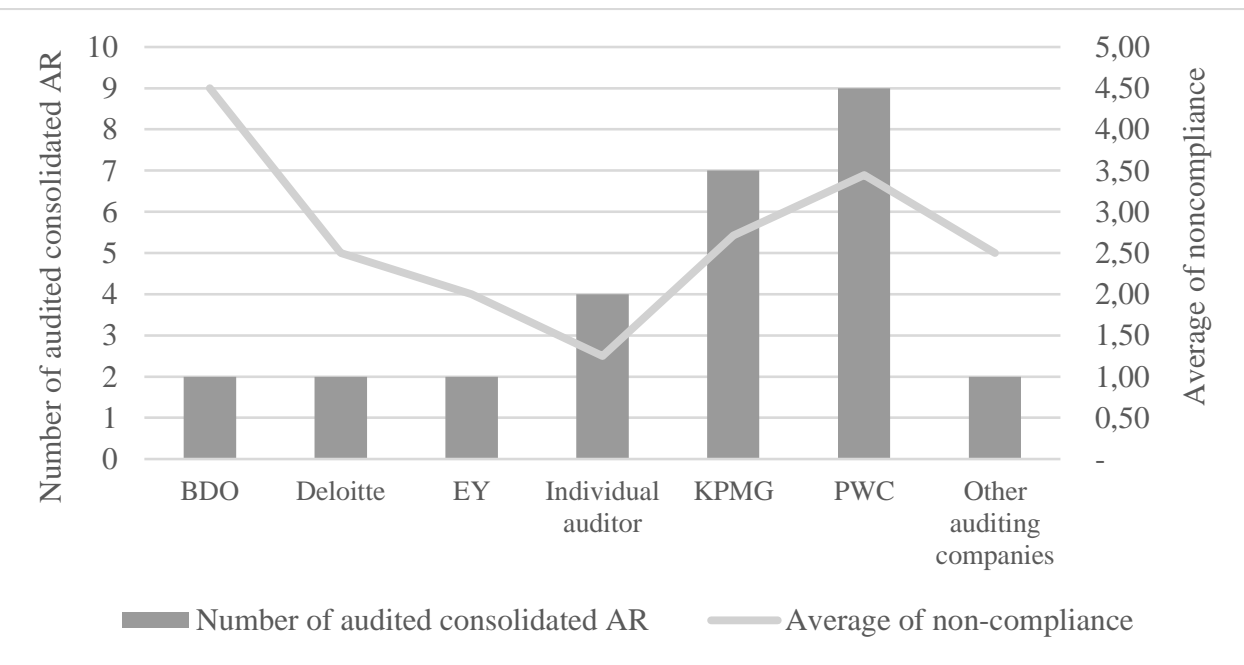

Source: Own research

Tab. 5: Anova

\begin{tabular}{cc}
\hline $\boldsymbol{F}$ & $\boldsymbol{P}$-value \\
\hline 0.9351 & 0.4908 \\
\hline
\end{tabular}

Source: Own research

Analysis of variance has established that there exist an association between the level of non-compliance and the statutory auditor of the company.

Is the level of compliance correlated with the relative share of inventories?

Tab. 6: Association of non-compliance level with share of inventories on total assets

\begin{tabular}{lrr}
\hline & $\mathbf{2 0 1 7}$ & $\mathbf{2 0 1 6}$ \\
\hline Pearson`s Correl. Coeff. & -0.2702 & -0.2552 \\
P-value & 0.9979 & 0.9978 \\
\hline
\end{tabular}

Source: Own research

Association between the level of non-compliance and the share of inventories on the total assets was not proven. 
To summarise it can be said that the level of disclosure compliance with IAS 2 by issuers on PSE is comparable to the compliance with other standards as investigated in previous studies mentioned above. Studies performed by Dvořák, Červený, Brabcová and Čavela have brought similar results to the presented study in that most companies complied with the IFRS requirements in their examined area. Only the study by Novák revealed a worse level of compliance when compared to the others.

\section{Conclusion}

The aim of this article is to identify the compliance with IAS 2 in consolidated financial statements of the issuers of listed shares on PSE. The results of the correlation analysis proved that in the examined sample of consolidated financial statements, there is an association between the sum of inventories and the sum of assets. An opposite examination can be interpreted in a way that the sum of inventories in this sample's consolidated financial statements had no impact on the sum of allowances to inventories. Also no association between noncompliance with the IAS 2 requirements and the sum of total assets nor the sum of inventories was proven. Even the number of years listed on PSE has no impact on the compliance measurement.

Furthermore, the investigation indicated that, on average, the issuers of the listed shares in the examined sample did not comply with three of the IAS 2 requirements in their consolidated financial statements. For the issuers in the examined sample, the most problematic requirement of IAS 2 was to present a reversal of a write-down where $71 \%$ of the issuers did not comply. The second most often non-complied requirement was to present a reason of a write-down where $68 \%$ of the issuers did not comply. Presentation of pledged inventories was the third biggest area of noncompliance, which was not stated in $64 \%$ of the examined issuers' consolidated statements.

The main limitation is the fact that it cannot be stated with certainty whether an issuer did not comply with the IAS 2 requirements and omitted the presentation in the consolidated annual report, or whether the requirements of IAS 2 were not relevant for them and therefore not presented in the consolidated annual report. The research results may affect users of consolidation statements, mainly in the area of reliance of presented values.

In the future, further potential examined area could be the YtY change (2018/2017) comparison of the compliance with IAS 2 in consolidated financial statements of the 
Polachová, K.: Compliance with IAS 2 in Consolidated Financial Statements of PSE Listed Companies.

issuers of listed shares on PSE. Furthermore, beneficial could be an extension of the examined area to the association between profit before tax and the sum of allowances and an extension of the compliance requirements of IAS 2 within the scale of 5 marks, with 1 meaning the full compliance instead of simple answers of yes or no. Comparison of the compliance with the IAS 2 requirements in the Visegrad Four presents another possibility of the research's expansion.

\section{References}

Askew S., Jeffers A. E., 2010. Analyzing Financial Statements under IFRS Opportunities \& Challenges, Journal of Leadership, Accountability and Ethics, Vol. 8, Iss. 1, pp. $45-56$.

Barbu E., Dumontier P., Feleaga N., Feleaga L., 2014. Mandatory Environmental Disclosures by Companies Complying with IAS/IFRS: The Case of France, Germany and the UK, The International Journal of Accounting 49 (2014) 231-247. DOI: 10.1016/j.intacc.2014.04.003.

Brabcová B., 2018. Compliance with IAS7 by Issuers of Listed Securities in the Czech Republic, European Financial and Accounting Journal, University of Economics, Prague, vol. 2018, issue 3, pp. 73-89. DOI: 10.18267/j.efaj.215.

Czech National Bank. Regulated institutions and registered financial market entities lists. Available from: <apl.cnb.cz/apljerrsdad/JERRS.WEB07.INTRO_PA GE?p_lang=cz>. [17 February 2019]

Čavela D., 2016. Quality of Information Disclosed in Annual Reports of Listed Companies in the Czech Republic. European Financial and Accounting Journal, University of Economics, Prague, vol. 2016, issue 2, pp. 21-36. DOI: 10.18267/j.efaj.155.

Červený M., 2017. Fulfillment of IFRS 2 Disclosure Requirements by Companies Listed on the Prague Stock Exchange. European Financial and Accounting Journal, University of Economics, Prague, vol. 2017, issue 3, pp. 53-64. DOI: 10.18267/j.efaj.187.

Dvořák J., 2017. How Do Czech Companies Report Fair Value Measurement Under IFRS 13?, European Financial and Accounting Journal, University of Economics, Prague, vol. 2017, issue 3, pp. 117-128. DOI: 10.18267/j.efaj.191.

IAS 2 - Inventories. Available from: <iasplus.com/en/standards/ias/ias2>. [10 April 2018].

IFRS. IFRS Foundation 2017. Available from <ifrs.org/>. [20 April 2018].

IAS 2. Available from: <ec.europa.eu/internal_market/accounting/docs/consolida ted/ias2_en.pdf>. [20 April 2018]. 
Král B., 2014. International accounting standard 2 - Inventories and Czech Accounting Legislation. Český finanční a účetní časopis, University of Economics, Prague, vol. 2014, issue 3, pp. 107-121. DOI: 10.18267/j.cfuc.412.

Krishnan, S., \& Ping, L., 2012. Inventory Valuation under IFRS and GAAP. Strategic Finance, 93(9), 51-58.

Mateiu M., 2013. Research Disclosure of IAS 2, IAS 11 and IAS 37 in Companies Listed on the Stock Market of London, Germany and Paris, 5 Res. \& Sci. Today 166.

Monea A., 2011. Some aspects regarding implications of IAS 2 "Inventory" in Romanian accounting, Annals of the University of Petroşani, Economics, 11(4), 2011, 183-190.

Mulford, C. W., Comiskey, E. E., and Thomason, J., 2008. The potential consequences of the elimination of LIFO as part of IFRS convergence. Report, Georgia Institute of Technology, December, Available from: <http://smartech.gatech.edu/handle/1853/26316>.

Novák M., 2018. The Quality of Disclosure under IAS 38 in Financial Statements of Entities Listed on PSE. European Financial and Accounting Journal, University of Economics, Prague, vol.18, issue 2, pp. 31-44. DOI: 10.18267/j.efaj.208.

Sytnik O.E., 2013. Difficulty of international financial reporting standards agricultural organizations. Sytnik O.Е. Сборник научных трудов Sworld. T. 37. № 4. C. 31-34.

Tsalavoutas I., Andre P. \& Evans L., 2012. The transition to IFRS and the value relevance of financial statements in Greece, British Accounting Review, 44 (4), pp. 262-277. DOI: $10.2139 / \mathrm{ssrn} .1286474$. 
Polachová, K.: Compliance with IAS 2 in Consolidated Financial Statements of PSE Listed Companies.

\section{Appendix 1: Issuers}

\begin{tabular}{|r|l|}
\hline Issuer's Number & \\
\hline 1 & České dráhy, a.s. - Railway \\
\hline 2 & HB Reavis Finance CZ, s.r.o.- Real estate \\
\hline 3 & ORCO PROPERTY GROUP S.A. - Real estate \\
\hline 4 & NET4GAS, s.r.o. - Gas \\
\hline 5 & O2 Czech Republic a.s. - Telecommunications \\
\hline 6 & ŠKODA TRANSPORTATION a.s. - Industrial Transportation \\
\hline 7 & CZECHOSLOVAK GROUP a.s. - Manufacturing - defence and civilian production \\
\hline 8 & ČD Cargo, a.s - Industrial Transportation. \\
\hline 9 & MND a.s. - Gas \\
\hline 10 & Philip Morris ČR a.s.- Tobacco \\
\hline 11 & PFNonwovens a.s. - Textile \\
\hline 12 & Tatry mountain resorts, a.s. - Hotel \\
\hline 13 & Pražská plynárenská, a.s. - Gas \\
\hline 14 & Kofola ČeskoSlovensko a.s. - Beverages \\
\hline 15 & AQUAPALACE, a.s. - Entertainment \\
\hline 16 & Česká zbrojovka a.s. - Manufacturing - arms \\
\hline 17 & TOMA, a.s. - Beverages \\
\hline 18 & EUC a.s. - Healthcare \\
\hline 19 & ENERGOAQUA, a.s. - Energy \\
\hline 20 & Teplárna Otrokovice a.s. - Energy and electricity \\
\hline 21 & BigBoard Praha, a.s. - Advertising \\
\hline 22 & UNICAPITAL ENERGY a.s. - Heat and electricity \\
\hline 23 & KAROSERIA a.s. - Rental \\
\hline 24 & TESLA KARLÍN, a.s. - Telecommunications \\
\hline 25 & E4U a.s. - Energy \\
\hline 26 & Deutsche Telekom AG - Telecommunications \\
\hline 28 & ČEZ, a. s. - Heat \\
\hline & EP Infrastructure, a.s. - Energy \\
\hline
\end{tabular}

